\title{
A study on pathological aspects of Xanthomonas campestris pv. campestris causing black rot of cabbage under red lateritic zone of West Bengal
}

\author{
Atit Maji ${ }^{1}$ and Ranjan Nath ${ }^{2 *}$ \\ ${ }^{1}$ Ramkrishna Ashram Krishi Vigyan Kendra, Nimpith, South-24 Parganas, West Bengal, INDIA \\ ${ }^{2}$ Dept. of plant protection, Palli Siksha Bhavana, Sriniketan, Visva Bharati, Birbhum, West Bengal, INDIA \\ *Corresponding author. E-mail: majirajeev@gmail.com
}

Received: January 25, 2015; Revised received: August 1, 2015; Accepted: October 2, 2015

\begin{abstract}
Cabbage, is one of the most important crops of the cole group of vegetables. In India it ranks next to cauliflower in acreage and first in production among cole crops occupying an area of 3,72,000 ha with annual production of 8534,000 tons. It covers about $4.3 \%$ area under vegetable crops in India. In West Bengal cabbage covers 78200.00 ha of area and the total production is 2197400.00 MT. Black rot is a major disease of cabbage (Brassica oleracea var. capitata), caused by Xanthomonas campestris pv. campestris (Xcc). The disease has been observed in all cabbage growing areas of Bolpur, Birbhum, West Bengal. The present study was carried out on the pathology of black rot disease of cabbage. Morphological, cultural, biochemical, and physiological characteristics of the pathogen were studied. The bacterium produced small, yellow, circular, entire, smooth and shining colonies in the culture medium. The optimum temperature for the growth was found $30^{\circ} \mathrm{C}$ and white light supported maximum growth of the bacterium. Nutritional studies revealed that sucrose gave maximum growth followed by maltase, lactose, dextrose and fructose as the carbon source in the nutrient broth. Black rot of cabbage pathogen also infected other crops of crucifereae family such as Cauliflower, Knol khol, Mustard, Radish and Rape seed. These findings regarding the pathogen may help to formulate the more appropriate way and judicious application of different management options against the diease in this zone.
\end{abstract}

Keywords: Black rot, Cabbage, Pathology, Xanthomonas campestris pv. campestris

\section{INTRODUCTION}

Cabbage, (Brassica oleracea var. capitata L) a member of family Brassicaceae, is one of the most important cole crops. It is a rich source of vitamin A, $\mathrm{B}, \mathrm{C}$ and minerals like phosphorus, potassium, sodium and iron. In India it ranks next to cauliflower in acreage and first in terms of production among cole crops occupying an area of $3,72,000$ ha with annual production of 8534,000 tons (Anonymous, 2013). In West Bengal cabbage covers 78200.00 ha and the total production was $2197400.00 \mathrm{MT}$ (Anonymous, 2014). The plant pathogenic bacterium Xanthomonas campestris pv. campestris $(X c c)$ causes black rot in a large number of crucifers worldwide (Alvarez, 2000). Advanced systemic infections can cause darkened leaf veins and stem vascular tissue, extensive leaf yellowing, leaf wilting and necrosis (Popovic' et al., 2013). $X$. campestris pv. campestris is the most important and widely distributed plant pathogenic bacterium on brassicas. It is the causal agent of black rot, a vascular bacterial disease, and commercially one of the most important diseases on brassicas (Janse, 2005.) Mahiar and Khalif (1999) reported that X. campestris pv. campestris attacks all members of cruciferaceae family. The black rot disease in India was first reported on cabbage from Bombay, Maharastra (Patwardhan, 1928). Presently it is found in all parts of the country including West Bengal, Maharastra, UP, HP, rajasthan, Delhi and Meghalaya (Singh and Dhar 2010). Black rot caused by $X$. campestris pv. campestris is the major constraint to cabbage production in tropical areas. Diseased crops have a poor market value, and are unsuitable for storage as they quickly rot after harvest and yield losses of up to $100 \%$ have been experienced (Walangululu and Mushagalusa, 2000; Massomo et al., 2003). Akhtar (1989) identified the pathogen causing black rot on cabbage as $X$. campestris pv. campestris based on the biochemical, physiological and pathogenicity characteristics of the isolate from cabbage. This is thought to be the first report of this pathogen on cabbage from Islamabad, Pakistan. The aim of the present work was to investigate the cultural, morphological, physiological and biochemical characteristics of the causal bacterium in the said zone.

\section{MATERIALS AND METHODS}

\section{Isolation and purification of the pathogen}

Selection of plant materials: For isolation of bacterial plant pathogens, at first the selection of the material was done appropriately. From young developing lesions the bacteria was isolated. Wherever, the 
diseased specimen did not contain young lesions, the young lesions were produced by artificial inoculation on to the healthy host plant and those lesions were used for isolation. Cabbage leaves showing symptoms of bacterial blight were collected from the Agricultural Farm of Palli Siksha Bhavana (College of Agriculture), Sriniketan, Visva-Bharati, Birbhum, West Bengal. The presence of bacterium was confirmed by performing the ooze test under the microscope.

Preparation of suspension for isolation: To isolate the bacterium, diseased portion adjacent to the healthy tissue were cut, surface sterilized for $1 \mathrm{~min}$. in freshly prepared $0.1 \% \mathrm{HgCl}_{2}$ solution and washed thoroughly thrice with sterile distilled water. The leaf bits were then transferred separately into a few drops of sterile water on a sterilized glass slide in an aseptic condition. The diseased bits were given a cut with sharp sterilized blade. The cut bits were left for few minutes to allow bacterial ooze to come out in the water. The suspension thus prepared was used for isolation.

Streaking the plates and slants: About $20 \mathrm{ml}$ of the molten nutrient agar was poured in each Petri plates and was allowed to solidify for $1 \mathrm{hrs}$. After that the plates were kept upside down. After 2-3 hrs these plates were used for isolation purpose. A loopful of the suspension prepared as in the preceding section, was streaked over the agar surface by the inoculation needle in a zig zag fashion. Two more plates were streaked without recharging the needle with bacterial suspension. Similarly culture slants were also prepared. The plates and the slants were labeled and were incubated at $28 \pm 2^{0} \mathrm{C}$ in a B.O.D. incubator and were examined daily.

Inoculums preparation: To maintain uniformity of inoculums, the bacteria growing on yeast extract glucose chalk agar slants, were gently brought into suspension by adding $10 \mathrm{ml}$ of sterile distilled water per culture tube and scrubbing the bacterial growth. The suspension so obtained was centrifuged at 5000 rpm for $10 \mathrm{~min}$, supernatant discarded and the pallete was re-suspended and the process was repeated thrice by adding fresh $10 \mathrm{ml}$ of sterile distilled water after each centrifugation. The finally washed suspension was used as inoculums.

\section{Characterization and identification of bacterium:}

For understanding and identification of bacterium, its morphological, cultural, physiological and biochemical characteristics were studied following standard procedure (Pelezar,et al., 1957; Dowson, 1957; Dye, 1962; and Ryu, 1980).

Morphological characteristics: Following staining methods were used to study the morphological characteristics of bacterial cells.

Gram's differential staining: A thin bacterial smear was prepared from one day old culture on grease free glass slide. It was air dried, heat fixed and covered with ammonium oxalate crystal violet (primary stain) for one min. and washed in tap water for not more than
2 sec. Gram's iodine solution was then applied for one min. and washed in tap water. Ethyl alcohol was added drop by drop to wash the primary stain and counter stained with Safranin for $30 \mathrm{sec}$. Then washed in tap water, air dried and examined under oil immersion objective lens of a compound microscope (Dowson, 1957).

Negative staining of bacteria: In cytological studies it is very important to obtain more accurate picture of bacterial cell. This can be achieved by negative staining or relief staining. A suspension of a $24 \mathrm{~h}$ old bacterial culture was prepared in sterile water. A small drop of nigrosin solution $(10 \% \mathrm{w} / \mathrm{v})$ close to the end of a grease free slide was placed and a loop full of the bacterium was poured into the drop of stain. Both were mixed thoroughly with the help of a thin glass rod. A slide was placed against the drop of suspended bacteria at an angle of $45^{\circ}$ and the drop was allowed to spread along the edge of the applied slide. The slide was air dried and was examined under oil emersion objective of a light microscope.

Cultural characteristics: The bacterium was grown on nutrient agar, potato dextrose agar and yeast extract glucose chalk agar in Petri plates. Inoculated Petri plates were incubated at $28 \pm 2^{0} \mathrm{C}$. After 3 days of incubation, characters of bacterial colonies were studied under stereoscopic microscope. The colonies were observed up to 10 days.

Biochemical characteristics: The biochemical characteristics of bacterium causing black rot of cabbage, were determined by following different tests. Fresh (48 hrs old) bacterial culture was used for all the tests.

Starch hydrolysis: Inoculation was made at three places on starch agar medium in Petri plates. Incubated at $28 \pm 2{ }^{0} \mathrm{C}$ for 7 days and then flooded with Lugol's iodine solution (Iodine $1 \mathrm{~g}$, KI $2 \mathrm{~g}$, distilled water 300 $\mathrm{ml})$. The formation of clear zone around the growth of bacterium indicated the hydrolysis of starch (Pelezar et al., 1957).

Gelatin liquefaction: Inoculation were made at different spots on gelatin medium in Petri plates and were, incubated at $28 \pm 2{ }^{0} \mathrm{C}$ for 2 days. These Petri plates were flooded with 8-10 ml mercuric chloride solution $\left(\mathrm{HgCl}_{2} 15 \mathrm{~g}\right.$, conc. HCL $20 \mathrm{ml}$ distilled water $\left.100 \mathrm{ml}\right)$. Liquefaction of gelatin was indicated by clear zone around bacterial growth (Pelezar et al., 1957).

Hydrogen sulphide production: Dry sterilized filter paper strips soaked in saturated lead acetate solution, were suspended in inoculated peptone water tubes along with cotton plugs and incubated at $28 \pm 2{ }^{\circ} \mathrm{C}$ for 14 days. The blackening of strips indicated liberation of $\mathrm{H}_{2} \mathrm{~S}$.

Physiological characteristics: The effect of temperature and light on the growth of the bacterium was studied for the characterization of the bacterium under investigation.

Effect of temperature: To study the effect of different 
Table 1. Cultural characteristics of Xanthomonas campestris pv. campestris on different solid media after three days of incubation at $28 \pm 2^{\circ} \mathrm{C}$.

\begin{tabular}{llll}
\hline Colony characters & Nutrient agar & $\begin{array}{l}\text { Potato dextrose } \\
\text { agar }\end{array}$ & $\begin{array}{l}\text { Yeast extract glucose } \\
\text { chalk agar }\end{array}$ \\
\hline Colour & Pale lemon yellow & Empire yellow & yellow \\
Form & Circular & Circular & Circular \\
Margin & Entire smooth & Entire smooth & Entire smooth \\
Elevation & Convex & Flat & Convex \\
Size & $10 \mathrm{~mm}$ & $7 \mathrm{~mm}$ & $10 \mathrm{~mm}$ \\
Pigmentetion & Light yellow & Light creamy yellow & yellow \\
\hline
\end{tabular}

Table 2. Biochemical Characteristics of the black rot of cabbage causing bacterium Xanthomonas campestris pv. campestris.

\begin{tabular}{cll}
\hline S.N. & Biochemical characteristics & Result \\
\hline 1. & Starch hydrolysis & Positive \\
2. & Gelatin liquefaction & Positive \\
3. & Hydrogen sulphide production & Positive \\
\hline
\end{tabular}

Table 3. Growth of Xanthomonas campestris pv. campestris after $60 \mathrm{~h}$ of incubation on basal medium at different temperatures.

\begin{tabular}{lcc}
\hline Temp $^{\mathbf{r}}\left({ }^{\mathbf{0}} \mathbf{C}\right)$ & Optical density (absorbance) \\
\hline 20 & & 0.0065 \\
25 & & 0.0262 \\
30 & & 0.0377 \\
35 & 0.0262 \\
SE(treatment mean) & $=$ & 0.000716 \\
$\mathrm{CD}$ at $5 \%$ & $=$ & 0.002335 \\
$\mathrm{CV}$ & $=$ & 5.430480 \\
\hline
\end{tabular}

Table 4. Effect of different lights of colour on the growth of Xanthomonas campestris pv. campestris after $60 \mathrm{~h}$ of incubation at $28 \pm 2^{0} \mathrm{C}$.

\begin{tabular}{|c|c|}
\hline Light source & $\begin{array}{l}\text { Optical density } \\
\text { (absorbance) }\end{array}$ \\
\hline White & 0.033 \\
\hline Red & 0.021 \\
\hline Yellow & 0.032 \\
\hline Green & 0.019 \\
\hline Blue & 0.003 \\
\hline Complete dark & 0.003 \\
\hline Alternate light and dark & 0.027 \\
\hline $\mathrm{SE}($ treatment mean) & 0.001846 \\
\hline $\mathrm{CD}$ at $5 \%$ & $=0.005599$ \\
\hline $\mathrm{CV}$ & $=15.751473$ \\
\hline
\end{tabular}

temperatures on the growth of bacterium, four different temperatures were taken ranging from $20^{\circ} \mathrm{C}$ to $35^{\circ} \mathrm{C}$ with an interval of $5^{\circ} \mathrm{C}$. Twenty ml nutrient broth was dispensed in each $100 \mathrm{ml}$ conical flasks, autoclaved and inoculated with $0.2 \mathrm{ml}$ of bacterial suspension. One flask from each treatment was kept as blank. Bacterial growth in terms of optical density was measured at $620 \mathrm{~nm}$. wave length of U.V. light after 60 hrs of incubation at different temperature .

Effect of light: To investigate the effect of different light on the growth of bacterium, transparent cellophane paper of different colours viz., colourless, yellow, green, blue, red and carbon paper for complete darkness were used. $100 \mathrm{ml}$ conical flasks containing $20 \mathrm{ml}$ of the nutrient broth were autoclaved, inoculated and wrapped with particular coloured paper and kept under artificial light source (100 watt bulb) along with control without inoculation. The bacterial growth in term of optical density (absorbance) was measured after $60 \mathrm{~h}$ of incubation at $28 \pm 2^{\circ} \mathrm{C}$.

\section{Nutritional Characteristics}

Carbon sources: To study carbon requirement, the different carbon sources (dextrose, sucrose, maltose, fructose and lactose) were used to prepare the nutrient broth medium. The $\mathrm{pH}$ of the medium was adjusted to 7.0 for each treatment. $100 \mathrm{ml}$ conical flasks containing $20 \mathrm{ml}$ of the nutrient broth prepared with different carbon sources were autoclaved. One $\mathrm{ml}$ of bacterial suspension was then added to each treatments in an aseptic condition and the resultant growth was measured in terms of optical density (absorbance) after 72 hrs of incubation at $28 \pm 2^{0} \mathrm{C}$.

Host range study: To determine the host range of $X$. campestris pv. campestris, 10 different plant species, belonging to three different families, were inoculated through carborundum abrasion technique and the disease development was recorded, if any. Two months old leaves were selected for inoculation suitable controls were maintained in each case.

\section{RESULTS AND DISCUSSION}

Morphological characteristics: The morphology of bacterial cell was studied with different staining techniques i.e. Gram staining and negative staining of bacteria. The methods used are described in detail under materials and methods. The bacterium produced straw yellow, smooth, glistening colonies with entire margin and convex elevation on NA medium. The study clearly indicated that $X$. campestris $\mathrm{pv}$. campestris, black rot of cabbage pathogen, was gramnegative, short rod, mostly single and rarely in chains. Patel et al. (1951) and Orellana (1965) reported that the cells of $X$. campestris were rod shaped with rounded ends, borne singly or in short chains, $0.8 \times 1.7 \mu \mathrm{m}$ in size, gram negative, capsulated, unifllagellate, and non spore forming. Gram-negative, Cells are straight rods, usually within the range $0.4-0.7$ wide $\mathrm{x}$ 0.7-1.8 $\mu \mathrm{m}$ long, predominantly single. which are 
Table 5. Different carbon sources on the growth of Xanthomonas campestris pv campestris after $72 \mathrm{~h}$ of incubation at $28+2^{\circ} \mathrm{C}$.

\begin{tabular}{lcc}
\hline \multicolumn{1}{c}{ Carbon sources } & Optical density(absorbance) \\
\hline Dextrose & & 0.076 \\
Sucrose & & 0.118 \\
Maltose & & 0.096 \\
Fructose & 0.072 \\
Lactose & 0.081 \\
SE(treatment mean) & $=$ & 0.004835 \\
CD at 5\% & $=$ & 0.015235 \\
CV & $=$ & 9.459222 \\
\hline
\end{tabular}

same as present findings. Balan et al. (2014) The bacteria $X$. axonopodis pv dieffenbachiae produced slimy yellow colonies and were aerobic gram negative rods. It produced $\mathrm{H}_{2} \mathrm{~S}$, liquefied gelatin and hydrolyzed starch. X. campestirs pv. campestris (Pam.) Dowson. It is a small, rod shaped, aerobic, gram negative, nonspore forming bacterium described by Gupta et al. (2014).

Bacterium was rod shaped, Gram negative, single polar flagellate, capsulatedand non spore forming. All the morphological characteristics of the bacterial isolates are similar to the genus Xanthomonas (Dye 1968).

Cultural characteristics: After $48 \mathrm{~h}$ of incubation at $28 \pm 2^{\circ} \mathrm{C}$ bacterial growth appeared on all three different media as minute and transparent colonies. The colonies became light yellow on nutrient agar and yeast extract glucose chalk agar and light creamy yellow on potato dextrose agar media after $72 \mathrm{~h}$ of incubation. The size and colour of bacterial colonies on different solid media after three days of incubation at $28 \pm 2^{\circ} \mathrm{C}$ are presented in Table 1. The similar results were obtained by Hayward (1983), Mariano and Gama (2005) and Viana (2006) on nutrient agar medium. The Xanthomonas colonies were yellow and gummy on nutrient agar but colourless on potato dextrose agar media (Orellana, 1965).

Biochemical characteristics: Biochemical characteristics of the black rot of cabbage pathogen were studied as mentioned in materials and method and observations on various tests were given in Table 2 . The results showed that the black rot causing pathogen $X$. campestris pv. campestris hydrolyzed starch and could liquefy the gelatin. The pathogenic bacterium also produced hydrogen sulphide in peptone medium as confirmed by the blackening of the paper strip. Which was similar as described by (Radunović1 and Balaž, 2012). The present result was also supported by the results found earlier by Jambenal et al. (2011). The bacterium had a single polar flagellum and it was catalase positive, hydrogen sulphide positive, oxidase negative and did not produce nitrate or indole as reported by Gupta et al. (2014). Naqvi et al. (2013) reported that the isolates of $X$. campestris pv. campestris tested positive for $\mathrm{H}_{2} \mathrm{~S}$ production giving a black discoloration on lead acetate paper strips. This was similar to present study.

Physiological characteristics: Physiological characteristics of the black rot of cabbage pathogen were studied as mentioned in materials and method and observations are follows:

Effect of different temperatures: Temperature has a great influence on the rate of growth of living organisms including the bacteria owing to its effect on the chemical and physical processes involved in growth. To find out optimum temperatures for the growth of the bacterium, four different temperatures ranging from $20^{\circ} \mathrm{C}$ to $35^{\circ} \mathrm{C}$ with an interval of $5^{\circ} \mathrm{C}$ were set. Bacterial growth in terms of optical density was measured after $60 \mathrm{~h}$ of incubation at different temperatures. The average results obtained were presented in Table 3. Thimmegowda (2006) observed that isolates of $X$. oryzae pv. oryzae tested at different temperature levels showed maximum growth at $30^{\circ} \mathrm{C}$ to $35^{\circ} \mathrm{C}$ and the temperature of $10^{\circ} \mathrm{C}$ and $40^{\circ} \mathrm{C}$ supported the poor growth. The data in Table 3 indicated that the bacterium $X$. campestris pv. campestris could grow over a wide range of temperature from $20^{\circ} \mathrm{C}$ to $35^{\circ} \mathrm{C}$. The growth of bacterium gradually increased up to $30^{\circ} \mathrm{C}$ beyond which it decreased. The optimum tempera-

Table 6. Host range of Xanthomonas campestris pv campestris determined by inoculating two month old plants of different species using carborundum abrasion method.

\begin{tabular}{lcc}
\hline Name of Host & Reaction & Incubation period (days) \\
\hline Crucifereae & & $5-6$ \\
Cabbage (Brassica oleracea var.capitata) & + & $5-6$ \\
Cauliflower (Brassica oleracea var. botrytis) & + & $6-7$ \\
Knol khol (Brassica oleracea var caulrapa) & + & $6-8$ \\
Mustard (Brassica nigra) & + & $6-8$ \\
Radish (Raphanus sativus) & + & $7-8$ \\
Rape seed (Brassica napus) & & - \\
\hline Solanaceae & - & - \\
Chilli (Capsicum annum) & - & - \\
Tomato (Lycopersicon esculentum L.) & & - \\
\hline Leguminoceae & - & - \\
Pea (Pisum sativum var. arvense) & - & \\
Arhar (Cajanus cajan) & & \\
\hline
\end{tabular}


ture for growth was found $30^{\circ} \mathrm{C}$. It was also reported that the organism was found to grow well in between $27-35^{\circ} \mathrm{C}$ with optima in between $28-30{ }^{\circ} \mathrm{C}$ which supported the present observation. Similar study was conducted by Dye and Lelliott (1974), on the pathogen Xanthomonas oryzae pv. oryzae required $25^{\circ} \mathrm{C}$ to $27^{0} \mathrm{C}$ as optimum temperature for the good growth and could grow up to $30^{\circ} \mathrm{C}$.

Effect of light: To study the effect of different colour of light on the growth of the bacterium, transparent papers of different colours viz. white, red, yellow, green, blue and carbon paper for complete darkness were used. The optical density was measured after $60 \mathrm{~h}$ of incubation at $28 \pm 2^{\circ} \mathrm{C}$ and average results are presented in Table 4 . Among the five different lights, continuous yellow and white lights were better than red, green and blue lights for the growth of the bacterium. The growth was minimum under complete darkness and very less under blue light. Bacterial growth was moderate when incubated under alternate light and dark.

\section{Nutritional requirement}

Effect of different carbon sources on the growth of the bacterium: Carbohydrates are important for microorganisms as they supply energy and various basic units of molecules required for growth. However a great diversity has been observed in microorganisms. During present investigation five different carbon sources, were used individually to prepare the nutrient broth medium with equivalent amount of carbon as specified in materials and method. The resultant growth after $72 \mathrm{hr}$ in terms of optical density was recorded and presented in Table 5. The present data showed that the growth of the bacterium was highest in the medium with sucrose as the carbon source $(0.118)$. The moderate growth of the bacterium was found in media with maltose $(0.096)$ and lactose $(0.081)$ as carbon sources. Tanaka (1964) reported that sucrose and glucose were the best carbon sources followed by fructose, galactose, mannitol and mannose. Xylose, lactose and starch were the poor carbon sources which were similar to the present investigation.

Host range: The pathogenic ability of $X$. campestris pv. campestris was tested on 10 plants species, belonging to three different families. Two month old leaves of test plant species were inoculated with bacterial suspension by carborundum abrasion technique. The inoculated plants were observed daily up to 30 days and disease development were recorded. The bacterium causing black rot of cabbage could produce visible symptoms only in plant species belong to the family crucifereae. The symptom expression took longer period of incubation (6-8 days) in Knol khol, Mustard, Radish and Rape seed as compared to cabbage and cauliflower Table 6. The bacterium attacked all members of cruciferae family including rutabaga, cabbage, savoy cabbage, broccoli, turnip, radish, kohlrabi, Lapidium sativum, Raphanus sativus var. caudatus, Brassica juncea, fodder cabbage, Capsella bursa-pastoris and Cantella asiatica (Mahiar and Khalif, 1999)

\section{Conclusion}

Bacterial growth appeared, on all three different media, as minute and transparent colonies. The colonies became light yellow on nutrient agar and yeast extract glucose chalk agar and light creamish yellow on potato dextrose agar media after $72 \mathrm{~h}$ of incubation. Continuous yellow and white lights were better than red, green and blue lights. The growth was minimum under complete darkness and very less under blue light. Bacterial growth was moderate when incubated under alternate light and dark. The growth of the bacterium was highest in the medium with sucrose as the carbon source. The moderate growth of the bacterium was found in media with maltose (0.096) and lactose (0.081) as carbon sources. The cultural, physiological and biochemical characteristics of the bacterium under investigation found similar to that of $X$. campestris pv. campestris. These findings regarding the pathogen may help to formulate the more appropriate way and judicious application of different management options against the disease.

\section{REFERENCES}

Akhtar, M.A. (1989). Xanthomonas campestris pv. campestris causing black rot in cabbage. Pakistan-Journal of Agricultural Research, 10 (3): 311-313

Alvarez, A.M. (2000). Black rot of crucifers. In: Slusarenko A.J., Fraser R.S.S., van Loon L.C. eds). Mechanisms of Resistance to Plant Diseases, pp. 21-52. Kluwer Academic Publishers, Dordrecht, The Netherlands.

Anonymous (2013). Indian Horticulture Database-2013. National Horticulture Board, Gurgaon, Ministry of Agriculture, Govt. of India

Anonymous (2014). Indian Horticulture Database-2014. National Horticulture Board, Gurgaon, Ministry of Agriculture, Govt. of India

Balan Sanju, Sajeesh, P. K. and Abraham Koshy, (2014). Morphological and biochemical characterization of Xanthomonasaxonopodis pv dieffenbachiae (McCulloh \& Pirone) causing bacterial blight of Anthurium (Schott.). Trends in Biosciences, 7 (8): 636-640

Dowson, W.J. (1957). Plant diseases due to bacteria. Cambridge University Press to London, pp.227.

Dye D.W. (1968). A taxonomic study of genus Erwinia amylovora group. New Zealand J Sci., 11: 590-607 Xanthomonas campestris on different media. Mikrobiologicheskii Zhurnal, 44: 36-40.

Dye, D. W. (1962). The inadequacy of the usual determinative tests for the identification of Xanthomonaas sp. $N$. Z. J. Sci. 5 : 393-416.

Dye, D. W. and Lelliott, R. A. (1974). Genus Xanthomonas. Bergey's Manual of Determinative Bacteriology. Ed. Buchanan, R. E.and Gibbons., Williams and Wilkins, N. E, Baltimore, 7:243-245.

Gupta Meenu, Amit Vikram and Narender Bharat (2014). black rot - a devastating disease of crucifers: A review. Agri. Reviews, 34 (4) : 269-278.

Hayward, A.C. (1983). Preliminary diagnosis of plant disease caused by bacteria. Plant Bacterial Disease : A Diagnostic 
Guide, pp. 1-22.

Jambenal, Shivananda, Ravikumar, M.R. and Hiremani, Neelakanth (2011). Basic studies on Xanthomonascampestris.pv. viticolacausing bacterial leaf spot of grape and evaluated in-vitroefficacy of different chemicals and bioagents against its growth. Internat. J. Plant Protec., 4 (2): 397-401.

Janse, J.D. (2005). Phytobacteriology - Principles and practice. CABI Publishing, USA

Mahiar, M. and Khalif, H. (1999). Black rot of in Jordan: sources of inoculums. Dirasat. Gric. Sci., $26: 329-337$.

Mariano, R. L. R. and Gama, M. A. (2005). Preservation methodsand growth of Xanthomonas campestris pv. viticola in culture medium at varying temperature, $\mathrm{pH}$ and $\mathrm{NaCl}$ concentrations. Fitopatologia Brasileira, 30(6) : 650-654.

Massomo, S.M.S., Hanne, N., Mansfield-Giese, K., Mabagala, R.B., Hockenhull, J., and Mortensen, C. N. (2003). Identification and characterisation of Xanthomonas campestris pv. campestris from Tanzania by pathogenicity tests, Biology, Eric- and Box-PCR and fatty acid methyl ester anal sis. European Journal of Plant Pathology, 109: 775-789.

Naqvi, S. F., M. Inam-ul-Haq, M. Ahsan Khan, M. Ibrahim Tahir, Zahid Ali and Rehman, H.M. (2013). Morphological and biochemical characterization of Xanthomonas campestris (pammel) dawson pv. sesami and it's management by bacterial antagonists. Pak. J. Agri. Sci., 50(2): 229235 .

Orellana, R.G., Thomas, C.A. and Kinman, M.L. (1965). A bacterial blight of guar in the United States. FAO, Plant. Prot. Bull., 13:9-13.

Patel, M.K., Dhande, G.W. and Kulkarni, Y.S. (1951). Studies in some species of Xanthomonas. Indian Phytopath., 4:123-140.

Patwardhan, G.B. (1928). Field, garden and orchard crops of Bombay. Presidency Bull. Dep. Agric. Bombay, 30.
Pelezar, M.J., Bard, R.C., Burnett, G.W., Conn, H.J., Demoss, R.D., Evans, E.E., Jennison, M.W., Mckee, A.P., Riker, A.J., Warren, J., Weeks, O.B., and . Weises, F.A. (1957). Manual of microbiology methods. McGraw Hill Book Co., New York: 305

Popovic,' T., Jošic', D., Starovic', M., Milovanovic', P., Dolovac, N., Poštic' D., and Stankovic' S. (2013). Phenotypic and genotypic characterization of Xanthomonas campestris strains isolatedfrom cabbage, kale and broccoli. Archives of Biological Science, 65: 585-593.

Radunović, D. and Balaž, J. (2012). Occurrence of Xanthomonascampestris pv. Campestris (Pammel, 1895).Dowson 1939, on Brassicas in Montenegro Pestic. Phytomed. (Belgrade), 27 (2): 131-140.

Ryu, E. (1980). Simple methods for staining of bacteria $2^{\text {nd }}$ Edition International laboratory for zoonoses Taipei, Taiwan Republic of China.

Singh D, Shri Dhar (2010). Bio-PCR based diagnosis of Xanthomonas campestris pathovars in black rot infected leaves of crucifers. Ind. Phytopath., 64: 7-11.

Tanaka, Y. (1964). Studies on the nutritional physiology of Xanthomonas oryzae (Uyeda et al., Ishiyama) Dowson. II. On the carbon source and a new synthetic medium. Science Bulletin Faculty of Agriculture Kyushu University, 21 (2, 3): 149-153.

Thimmegowda, P . R. (2006) Studies on bacterial leaf blight of paddy. M.Sc. (Agri.) Thesis, Univ. Agric. Sci. Dhawad (India).

Viana, I.O. (2006). Medium for isolation of Xanthomonas campestris pv. viticola. Ciencia-Rural, 36 (4):1317-1320.

Walangululu, J.M. and Mushagalusa, G.N. (2000). The major pests of cabbage (Brassica oleracea var. capitata subs. sabauda) in Bukavu and around. Tropicultura. International Journal of Systematic Bacteriology, 18: 55-57. 